\title{
Patient experiences with technology enabled care across healthcare settings- a systematic review
}

\author{
Ann-Chatrin Linqvist Leonardsen * (D), Camilla Hardeland, Ann Karin Helgesen and Vigdis A. Grøndahl
}

\begin{abstract}
Background: Healthcare services are facing extensive challenges due to the increased proportion of elderly persons and persons with chronic disease. Technology enabled care (TEC) is a collective term for telecare, telehealth, telemedicine, mobile (m)-, digital- and electronic (e) health services. TEC is increasingly seen as a solution to many of the challenges facing the health sector. Patient perspectives may provide a useful evaluation tool for new healthcare technologies that have limited clinical data to support their effectiveness. More studies need to be done to better understand the acceptance of technology in healthcare. This review aim to summarize empirical studies exploring patient experiences with TEC. Findings in this study can be used to better understand what is needed to develop, implement and improve such services.

Methods: Systematic searches were conducted in the Pubmed, Psycinfo, Cinahl, Embase, Cochrane systematic reviews and Cochrane clinical trials databases. These studies were systematically reviewed using the Preferred Reporting Items for Systematic Reviews and Meta-Analyses (PRISMA) guidelines, subjected to quality appraisals using the Critical Appraisal Skills Program (CASP), and synthesized via integrative analysis.
\end{abstract}

Results: After removal of duplicates, languages other than English, and non-scientific records, 4087 titles and abstracts were screened. After assessment against inclusion and exclusion criteria, 69 records were screened in fulltext, and underwent quality appraisal. 21 records were included in the integrative analysis. Patients' experiences with TEC related to 1) technological features, namely functionality and appearance, and 2) evolving independence, namely empowerment, autonomy and security. Technological challenges lead to frustrations and negative experiences, while a stigmatizing appearance lead to patients not using the solution. Through the use of TECs, patients felt more empowered, learning about their condition, increasing awareness to their symptoms and treatment, and feeling more safe and self-efficient. Patient participation was seen as a central aspect of the development of the TECT, as well as when using it.

Conclusion: This review deepens the understanding of patients' experiences with technology enabled care solutions. Patients' experiences not only relate to the practical/technical element of the device or solution, but to how this impact on their everyday life. Patient participation in development and planned use of such solutions should be considered an integral part in healthcare quality initiatives.

Keywords: Digital health, Technology enabled care, Telehealth, Telemedicine, E-health, Digitalization, Patient experiences

\footnotetext{
* Correspondence: ann.c.leonardsen@hiof.no

Department of Health and Welfare, Ostfold University College, Postal box code (PB) 700, NO-1757 Halden, Norway
}

(c) The Author(s). 2020 Open Access This article is licensed under a Creative Commons Attribution 4.0 International License, which permits use, sharing, adaptation, distribution and reproduction in any medium or format, as long as you give appropriate credit to the original author(s) and the source, provide a link to the Creative Commons licence, and indicate if changes were made. The images or other third party material in this article are included in the article's Creative Commons licence, unless indicated otherwise in a credit line to the material. If material is not included in the article's Creative Commons licence and your intended use is not permitted by statutory regulation or exceeds the permitted use, you will need to obtain permission directly from the copyright holder. To view a copy of this licence, visit http://creativecommons.org/licenses/by/4.0/ The Creative Commons Public Domain Dedication waiver (http://creativecommons.org/publicdomain/zero/1.0/) applies to the data made available in this article, unless otherwise stated in a credit line to the data. 


\section{Background}

Healthcare services are facing extensive challenges due to the increased proportion of elderly persons and persons with chronic disease [1-3]. Despite increasing treatment complexity, hospital length of stay is decreasing [4]. In addition, there are not enough healthcare professionals to manage the increasingly complex patient care needs [5]. These societal changes challenge the structure, finances and capacity of all healthcare service levels. Technology enabled care (TEC) is a collective term for telecare, telehealth, telemedicine, mobile (m)-, digital- and electronic (e) health services. TEC involves the convergence of health systems, digital media and mobile devices, which enables healthcare professionals and patients to access data and information more easily [6]. It is increasingly seen as an integral part of the solution to many of the challenges facing the health sector.

Most people nowadays own a smartphone or a tablet. This enables for patient participation, e.g. through the use of mobile applications, or apps [7-9]. The development and utilization of commercial smartphone apps are extensive and increasing, also related to management of health-related issues [10]. In addition, solutions for remote patient monitoring, where patients outside conventional clinical settings have been monitored with help of technology, have been implemented with the aims of increasing access to care and decrease healthcare delivery costs. Nevertheless, results are inconclusive on whether such solutions have the desired effects [11-14]. For example, research on remote monitoring of patients with lung cancer indicated that patients felt well informed, but that they lacked preparation for allpossible problemsthey could experience [15]. A recent study found that when daily automated monitoring, self-management coaching and follow-ups using guideline-based decision support were combined with in between-visit care, there were significant reductions in symptom burden overall for cancer patients beginning chemotherapy [16].

At the same time, healthcare services are moving away from the "doctor-knows-best" approach, towards a focus on person-centeredness, and with increased levels of patient-participation $[17,18]$. Research has shown that focus on person-centeredness leads to improved patient satisfaction, better health, a reduction in the number of hospitalization and re-hospitalizations, as well as economic benefits $[19,20]$. This is why national and international organizations have emphasized the importance of including patients and their perspectives in the development and evaluation of healthcare services [21-24]. Patient perspectives can provide important, relevant insight into the nature of patients' needs, the condition, and the treatment under consideration. Moreover, this may provide a useful evaluation tool for new healthcare technologies that have limited clinical data to support claims of effectiveness [25]. Experience-based measures differ from measures of satisfaction, which have previously been used as an index of how care has been received. 'Satisfaction' is often seen as the gap between patients' expectations and actual experiences. Hence, 'patients' experiences' provide more tangible information on how a service can be improved, and is less to prone to the influence of patient expectation, which is known to be influenced by varying factors [26-29].

There are various barriers to the deployment of TEC, such as concerns about quality, reliability, privacy and security. Moreover, it has been claimed that the design of TEC solutions have been technology-driven, without the involvement of the people they are made for [6]. A review from 2017 on recent advances in remote healthcare and patient monitoring claim that more studies needs to be done to better understand the acceptance of technology-based methods within the medical community and patients [30].

Consequently, this review aim to summarize empirical studies exploring patient experiences with technology enabled care solutions in relation to somatic diseases, treatment and care. Findings in this review may be used to better understand what is needed to develop, implement and improve such services.

\section{Methods}

A systematic mixed studies review with an intergrated design was undertaken to integrate and synthesize findings from qualitative, quantitative and mixed methods studies [31]. The design was chosen to gain a broader knowledge of patients' experiences with technology enabled care solutions in relation to somatic diseases, treatment and care, by exploring and describing studies that included different technology and different healthcare settings.

The literature was retrieved by searching in four electronic databases CINAHL via EBSCO, EMBASE and PsycINFO via OVID, PubMed via NCBI, in addition to the Cochrane systematic reviews and Cochrane clinical trials databases, in the period September 19th to October 20th 2019. A specialist librarian was consulted when developing the search strategy and also run the searches to ensure rigour in the search process. References were handled using the End-Note X8 and Rayyan QCRI software [32].

The Preferred Reporting Items for Systematic Reviews and Meta-Analyses (PRISMA) guidelines [33] were used to guide the systematic search and to structure the review, and the review adheres to the PRISMA guidelines (see supplement 1).

The search strategies were developed based on the following PICO framework [34] (see Table 1). The searches were not limited to time of publication or to study 
Table 1 PICO: Digital Health Care -somatic health

\begin{tabular}{lll}
\hline \multicolumn{3}{l}{ Systematic review: patient experiences with technology enabled care } \\
\hline P & I & C \\
\hline Somatic health & Digitalization & Safety \\
Patient & Digital Health & Quality \\
Illness & Medical treatment & Patient participation \\
& Health Care & Patient experience \\
& E-health & \\
& Technology enabled care & \\
& Telecare & \\
& Telemedicine & \\
& Telehealth \\
& Computer based technologies
\end{tabular}

design. Table 2 gives and overview of the search strategy in PubMed. Searches in the other databases were similar to the search strategy in PubMed, using the same terms and phrases, as well as Boolean operators.

Table 2 Search strategy in PubMed

\begin{tabular}{|c|c|c|}
\hline & PubMed Date for search: 19.09.2019 & Hits \\
\hline 1 & digitalization [tiab] & 957 \\
\hline 2 & digitalisation [tiab] & 178 \\
\hline 3 & "digital health" [tiab] & 1235 \\
\hline 4 & telecare [tiab] & 719 \\
\hline 5 & e-health [tiab] & 2550 \\
\hline 6 & technology [tiab] enabled [tiab] AND care [tiab] & 822 \\
\hline 7 & computer based technolog* [tiab] & 133 \\
\hline 8 & telehealth [tiab] & 4191 \\
\hline 9 & mobile technology [tiab] & 1356 \\
\hline 10 & m-health OR mhealth [tiab] & 4147 \\
\hline 11 & "mobile health" [tiab] & 3581 \\
\hline 12 & telemedicine [ti] OR telemedicine [mesh] & 26,786 \\
\hline 13 & $1-12$ med OR & 37,279 \\
\hline 14 & experience $^{*}[\mathrm{ti}]$ & 239,920 \\
\hline 15 & perspective* [ti] & 116,673 \\
\hline 16 & acceptance $^{*}$ ti] & 8655 \\
\hline 17 & participat* $[$ ti $]$ & 35,793 \\
\hline 18 & preference $^{*}[\mathrm{ti}]$ & 27,473 \\
\hline 19 & 14-18 med OR & 424,513 \\
\hline 20 & patient [ti] OR patients [ti] & $1,756,034$ \\
\hline 21 & 19 AND 20 & 42,745 \\
\hline 22 & Patient Satisfaction [majr] & 32,722 \\
\hline 23 & Patient Acceptance of Health Care/psychology [majr] & 14,173 \\
\hline 24 & 21 OR 22 OR 23 & 84,518 \\
\hline 25 & 13 AND 24 & 1044 \\
\hline
\end{tabular}

\section{Eligibility criteria}

Criteria for selecting studies were determined before the systematic literature search started, and was based on the aim of the review. The aim was explorative and descriptive, and the inclusion criteria reflect this.

Pre-defined inclusion criteria were:

- Patients aged $>18$ years

- Patient experiences

- All healthcare settings (including but not limited to primary, intermediate, tertiary, home care)

- Somatic diseases/dysfunctions

- Scandinavian and English language

- Peer-reviewed

Exclusion criteria were:

- Conference abstracts

- Unpublished material

- Dissertations

- Review articles

- e-Health technologies, alerts and reminder systems and information resources (e.g. Internet)

- eElectronic health records

\section{Study selection}

A modified flow chart shows the identification and selection process (see Fig. 1). The electronic database searches identified 5454 records. Duplicates were removed which resulted in 4310 records, and a further 223 records were excluded based on language and not being peer reviewed. A total of 4087 records were divided in two halves. Two and two of the authors independently and blinded to each others, screened the titles and abstracts according to their relevance, to ensure that the eligibility criteria and the aim of the study were met. As a result, 4018 records were rejected. A total of 69 articles were assessed in full text by two and two of the authors to ensure that the inclusion criteria were met, which left 69 papers to be assessed for quality.

\section{Appraisal and data extraction}

The Critical Appraisal Skills Programme Tools (CASP) for qualitative and quantitative studies [35] and a modified version by Nordström and Wilde-Larsson [36], were used for quality assessment of each paper included in the study. The appraisals related to e.g. whether the results were valid (clearly focused issue, appropriate method), if cases were recruited in an acceptable way, data collection justified, as well as ethical issues. The assessments were done by two authors independently. The results were then compared, and any differences on 


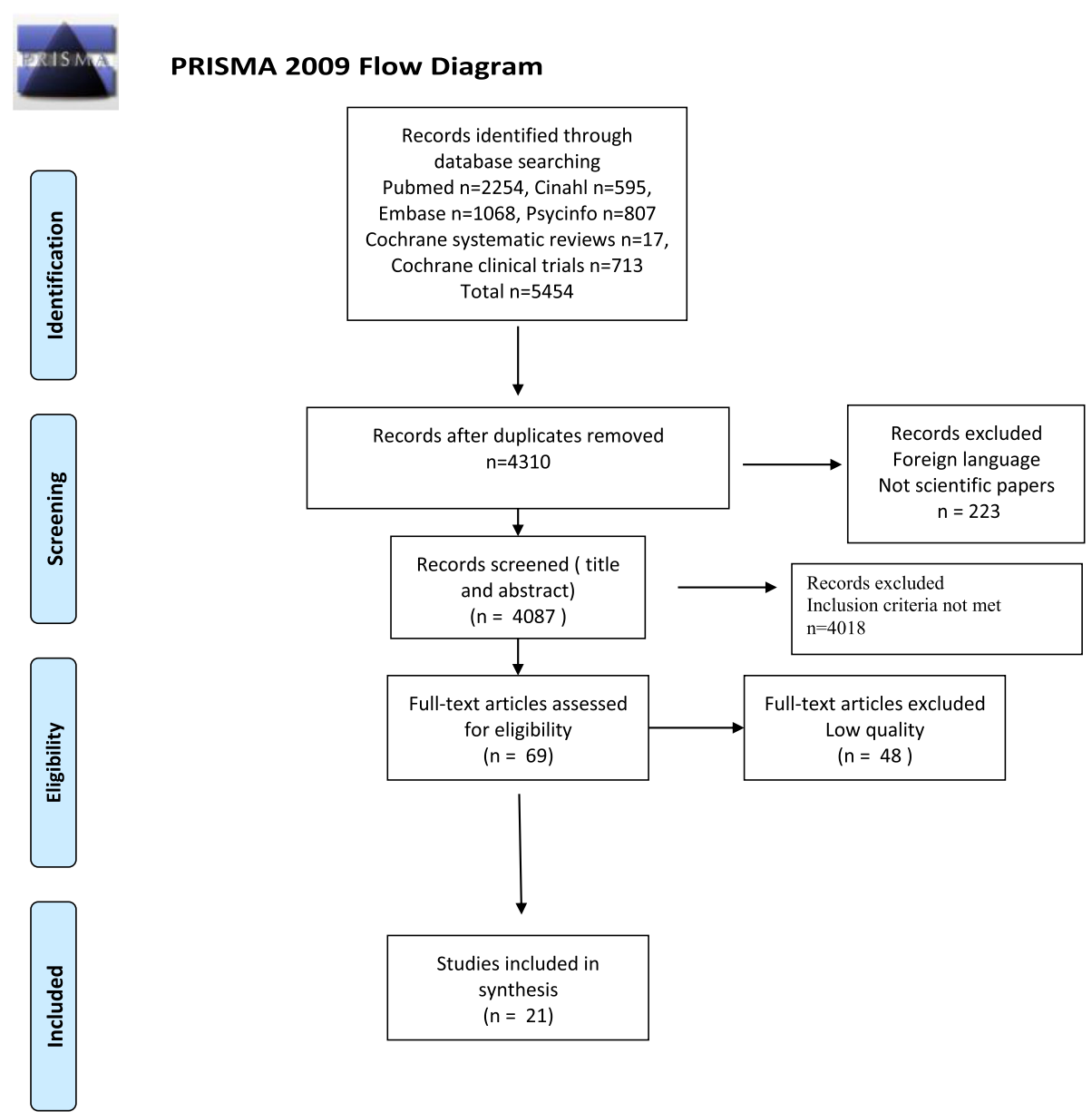

Fig. 1 PRISMA 2009 Flow Diagram

quality ratings were discussed until agreement was reached. A simple scoring system rated the papers to be of high, medium and low quality, and only high quality articles were included. A total of 48 articles were excluded based on low quality. All steps in the selection process, the appraisal and data extraction were performed by four independent researchers, that fulfills the requirements recommended by Higgins and Thomas [37]. Any differences or uncertainties were discussed by the authors until agreement was reached. In total 21 articles were included in the synthesis.

\section{Methods of synthesis}

An integrative analysis inspired by Sandelowski et al. [31] was conducted to synthesize the data. This method gave data the possibility to be grouped by findings addressing the same phenomenon instead, of by methods used in the studies. Confirmation and refutation are exercised when seeking to establish convergent validation (or triangulation) between qualitative and quantitative studies, respectively. Confirmation occurs when the same finding (e.g. positive experiences with a TEC) is repeated within and across both qualitative and quantitative studies. Refutation occurs when a designated relationship yields divergent findings, or findings in direct opposition [31]. The findings might be seen as extending each other, and as a kind of transformation of findings to be able to combine them, which is essential in the integrative analysis.

\section{Results}

\section{Study selection}

In total 4310 records were identified, of which 4098 records were screened for title and abstract. Of these, 69 full text records were screened and quality assessed, leading to a total of 21 publications included in the review. The included studies represent research from the period 2008-2019, of which 20 
was from the period 2013-2019. Of these, 12 studies used a qualitative design with interviews, six used a quantitative design with a survey, and three combined interviews and survey. The studies included a total of 695 participants (333 male), age range 18-88 years. Of the 21 studies, 19 reported the mean age of the participants. The mean of these were 61.9 years. The technology included telemonitoring $(n=5)$, sensors $(n=4)$, table computers $(n=4)$, fitbit $(n=3)$, applications $(n=2)$, a robotic rehabilitation device, a shortmessage self-management system, and an electronic pillbox. Six of the studies focused on type 2 diabetes, three on patients with chronic pulmonary lung disease (COPD), and two on cancer patients. Other conditions included Parkinsons' disease, motor neuron disease, cardiac disease, stroke, hypertension, dialysis patients, as well as patients with chronic/persistent pain. The studies' characteristics are presented in Table 3.

\section{Integrative analysis}

Results from the integrative analysis of the 21 included papers show that patients' experiences with technology enabled care solutions were divided into mainly two aspects; one aspect related to the technical features of the solution, and one aspect related to the solutions' impact on the patients' everyday life. The theme technical features included patients' experiences with the practical use of a digital device or solution, both related to functionality and appearance of the solution. Moreover, patients experienced an evolving independence in their everyday life due to the technology, through an increased feeling of empowerment, autonomy and security.

\section{Technical features}

To patients, it was imperative that the device or solution functioned well. For example, type 2 diabetes patients reported the importance of clearness of instructions, ease of use, convenience of location, and that the solution was easy to fit into daily routines. This implicated that they were satisfied with the solution $[40,47,55,56]$.

Nevertheless, patients also reported of technical challenges. One patient continuing stroke rehabilitation stated: «The keyboard is that frustrating I just couldn't be bothered trying to get it to work because it wouldn't» [40]. Other challenges reported by patients were oximetry transmission, device fault, mobile signal loss, immobility of the device, and difficulties placing the device on the body [40, 41, 46]. One study found that the device only functioned with wired internet that had to be connected through a cable through the telephone port in a patient's house, which was reported as a problem by patients [46]. In another study, the modems reportedly took a long time to send the data and sometimes did not actually send the data at all, leading to patients not being able to use the solution [41]. In a study on stroke rehabilitation, patients reported of difficulty putting the device on and adjusting it by themselves [41]. A frequent need to recharge was also reported as a disadvantage [38]. Technical challenges lead to a feeling of frustration, and dissatisfaction with the device or solution $[40,46,51]$.

Georgsson et al. found that type 2 diabetes patients saw clear benefits in using an m-Health system and had favorable behavioral disease outcomes after using it. Suggestions for improving the system were highly individual [44]. Need for individual tailoring was also reported in $57.8 \%$ of the respondents in a mobile weight-loss and lifestyle intervention for patients with type 2 diabetes, who reported that culturally tailoring of the program, addressing support mechanisms and improved site accessibility, enhanced their engagement [50].

Regarding appearance, $94.1 \%$ of patients with Parkinsons' disease were willing to wear body worn sensors at home, while $85.3 \%$ were willing to wear it in public [43]. One patient stated that he "Would prefer it to be a little smaller and with watch face as keep thinking it was a watch I was wearing". Another said that he would be "Happy to wear (in public) but would not like members of public questioning what it is for as illness is private". A perceived stigma and embarrassment, affecting when participants chose to wear the device was also reported in another study [53]. For example, bulkiness of the monitor was reported a negative feature of the appearance of a digital solution [41].

\section{Evolving independence}

Participants expressed an increased sense of independence from their newfound mobility for which they credited their use of the device [41, 58]. For example, $57.8 \%$ of the respondents in a mobile weightloss and lifestyle intervention to patients with type 2 diabetes reported that the mobile health technology promoted their self-efficacy [50]. COPD patients reported that telemonitoring empowered selfmanagement by enhancing their understanding of their illness, and providing additional justification for their decisions to adjust treatment or seek professional advice [42]. Moreover, a study on telemonitoring in motor neuron disease found that patients emphasized the benefits of timely intervention, reducing unnecessary actions and doctors' visits, making patients more self-aware and allowing them to take 
Table 3 Characteristics of articles included in the systematic review of studies exploring patient experiences with technology enabled care $(n=21)$, in alphabetic order

\begin{tabular}{|c|c|c|c|c|c|c|c|}
\hline $\begin{array}{l}\text { Authors/ } \\
\text { Country }\end{array}$ & Title & Aim & Design & Technology explored & Setting & $\begin{array}{l}\text { Sample, } \\
\text { including } \\
\text { participants' } \\
\text { characteristics }\end{array}$ & $\begin{array}{l}\text { Summary of relevant } \\
\text { findings }\end{array}$ \\
\hline
\end{tabular}

\begin{tabular}{|c|c|c|}
\hline $\begin{array}{l}\text { Ando, } \\
\text { Ashcroft-Kelso, } \\
\text { Halhead, } \\
\text { Chakrabarti, } \\
\text { Young, Cous- } \\
\text { ins, Angus } \\
2019 \\
\text { United } \\
\text { Kingdom (UK) } \\
\text { [40] }\end{array}$ & $\begin{array}{l}\text { Experience of } \\
\text { telehealth in } \\
\text { people with motor } \\
\text { neurone disease } \\
\text { using noninvasive } \\
\text { ventilation. }\end{array}$ & $\begin{array}{l}\text { To explore } \\
\text { subjective } \\
\text { experiences of } \\
\text { telehealth as } \\
\text { facilitated by the } \\
\text { Careportal }{ }^{\circledR} \\
\text { device as a } \\
\text { regular } \\
\text { monitoring } \\
\text { service amongst } \\
\text { people with } \\
\text { motor neuron } \\
\text { disease (MND) } \\
\text { who were using } \\
\text { noninvasive } \\
\text { ventilation (NIV). }\end{array}$ \\
\hline
\end{tabular}

\begin{tabular}{|c|c|c|}
\hline $\begin{array}{l}\text { Cherry, } \\
\text { Chumbler, } \\
\text { Richards, Huff, } \\
\text { Wu, Tilghman, } \\
\text { Butler } \\
2015 \\
\text { United States } \\
\text { (US) [41] }\end{array}$ & $\begin{array}{l}\text { Expanding stroke } \\
\text { tele-rehabilitation } \\
\text { services to rural } \\
\text { veterans: a qualita- } \\
\text { tive study on pa- } \\
\text { tient experiences } \\
\text { using the robotic } \\
\text { stroke therapy de- } \\
\text { livery and monitor- } \\
\text { ing system } \\
\text { programs. }\end{array}$ & $\begin{array}{l}\text { To determine } \\
\text { participants' } \\
\text { general } \\
\text { impressions } \\
\text { about the } \\
\text { benefits and } \\
\text { barriers of using } \\
\text { robotic therapy } \\
\text { device for in- } \\
\text { home } \\
\text { rehabilitation. }\end{array}$ \\
\hline
\end{tabular}

\begin{tabular}{|c|c|c|}
\hline $\begin{array}{l}\text { Fairbrother, } \\
\text { Pinnock, } \\
\text { Hanley, } \\
\text { McClughan, } \\
\text { Sheikh, } \\
\text { Pagliari, } \\
\text { McKinstry } \\
2013 \\
\text { United } \\
\text { Kingdom (UK) } \\
\text { [42] }\end{array}$ & $\begin{array}{l}\text { Exploring } \\
\text { telemonitoring and } \\
\text { self-management } \\
\text { by patients with } \\
\text { chronic obstructive } \\
\text { pulmonary disease: } \\
\text { a qualitative study } \\
\text { embedded in a } \\
\text { randomized con- } \\
\text { trolled trial. }\end{array}$ & $\begin{array}{l}\text { To explore } \\
\text { patients and } \\
\text { healthcare } \\
\text { professional } \\
\text { views on self- } \\
\text { management in } \\
\text { the context of } \\
\text { telemonitoring in } \\
\text { chronic obstruct- } \\
\text { ive pulmonary } \\
\text { disease (COPD). }\end{array}$ \\
\hline
\end{tabular}

\begin{tabular}{|c|c|c|c|c|}
\hline $\begin{array}{l}\text { Semi-structured } \\
\text { interviews after } \\
\text { completing a } \\
\text { 24-week trial. }\end{array}$ & $\begin{array}{l}\text { Telemonitoring } \\
\text { system, using the } \\
\text { Docobo }{ }^{\text {Ltd }} \text { Careportal }{ }^{\circledR} \\
\text { device. } \\
\text { Allows for monitoring } \\
\text { symptom changes, } \\
\text { noninvasive } \\
\text { ventilation (NIV) } \\
\text { related issues, } \\
\text { nocturnal blood } \\
\text { oxygen saturation } \\
\text { levels, and patient- } \\
\text { ventilator interaction } \\
\text { data. } \\
\text { In addition a } \\
\text { messaging system for } \\
\text { patient-clinician } \\
\text { communication. }\end{array}$ & At home & $\begin{array}{l}\text { An opportunity } \\
\text { sample of } 7 \\
\text { patients with } \\
\text { MND on NIV } \\
\text { were recruited. } \\
\text { Age: } 49-71 \\
\text { years (mean } 63 \\
\text { years) } \\
\text { Gender: } 2 \\
\text { women and } 5 \\
\text { men } \\
\text { Diagnosis: } \\
\text { Amyotrophic } \\
\text { lateral sclerosis }\end{array}$ & $\begin{array}{l}\text { Five themes } \\
\text { identified: } \\
\text { - benefits of timely } \\
\text { intervention } \\
\text { - reducing the } \\
\text { unnecessary } \\
\text { - increased self- } \\
\text { awareness } \\
\text { - taking initiative } \\
\text { - technical } \\
\text { challenges }\end{array}$ \\
\hline $\begin{array}{l}\text { Qualitative in- } \\
\text { depth semi- } \\
\text { structured inter- } \\
\text { views after 3- } \\
\text { months usage } \\
\text { periode of } 2 \text { h } \\
\text { of daily Robotic } \\
\text { Assisted Therapy } \\
\text { (RAT). }\end{array}$ & 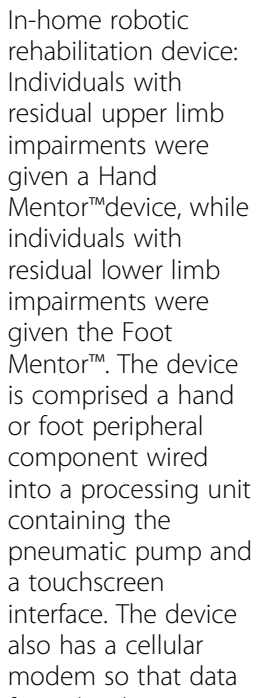 & At home & $\begin{array}{l}\text { A convenient } \\
\text { sample of } 10 \\
\text { veterans who } \\
\text { had } \\
\text { experienced a } \\
\text { unilateral } \\
\text { ischemic or } \\
\text { hemorrhagic } \\
\text { stroke. } \\
\text { Either hand } \\
\text { function or foot } \\
\text { function } \\
\text { significantly } \\
\text { limits activities } \\
\text { of daily living } \\
\text { Age: } 52-88 \\
\text { years (mean } 62 \\
\text { years) } \\
\text { Gender: } 10 \text { men }\end{array}$ & $\begin{array}{l}\text { Benefits of use: } \\
\text { - increased mobility } \\
\text { - a sense of control } \\
\text { over therapy and } \\
\text { scheduling } \\
\text { - an outlet for } \\
\text { physical and } \\
\text { mental tension and } \\
\text { anxiety } \\
\text { - increased } \\
\text { independence and } \\
\text { mood } \\
\text { improvement } \\
\text { Barriers to use were } \\
\text { few: } \\
\text { - size and placement } \\
\text { of the device } \\
\text { - technical } \\
\text { difficulties } \\
\text { - wearing and } \\
\text { adjusting the } \\
\text { device }\end{array}$ \\
\hline
\end{tabular}

from the therapy

could be sent to a

secure server to be

monitored by a

therapist. The device

is powered through a wall-outlet.

Semi-structured Telemonitoring
interviews six
months into the
randomized
controlled trial.
At home A purposively Telemonitoring sample of 38 increased patients knowledge of their Age: 44-85 condition, reinforced years (mean 67, their decisions to 4 years) adjust to treatment Gender: $20 \quad$ or seek professional women and 18 advice; and, through men practitioner Diagnosis: monitoring COPD provided a sense of reassurance. -Knowledge and empowerment -Accessibility and reassurance 
Table 3 Characteristics of articles included in the systematic review of studies exploring patient experiences with technology enabled care $(n=21)$, in alphabetic order (Continued)

\begin{tabular}{|c|c|c|c|c|c|c|c|}
\hline $\begin{array}{l}\text { Authors/ } \\
\text { Country }\end{array}$ & Title & Aim & Design & Technology explored & Setting & $\begin{array}{l}\text { Sample, } \\
\text { including } \\
\text { participants' } \\
\text { characteristics }\end{array}$ & $\begin{array}{l}\text { Summary of relevant } \\
\text { findings }\end{array}$ \\
\hline
\end{tabular}

\begin{tabular}{|c|c|c|c|}
\hline $\begin{array}{l}\text { Fisher, } \\
\text { Hammerla, } \\
\text { Rochester, } \\
\text { Andras, } \\
\text { Walker } \\
2016 \\
\text { United } \\
\text { Kingdom (UK) } \\
\text { [43] }\end{array}$ & $\begin{array}{l}\text { Body-worn sensors } \\
\text { in Parkinson's } \\
\text { disease: evaluating } \\
\text { their acceptability } \\
\text { to patients. }\end{array}$ & $\begin{array}{l}\text { To evaluate the } \\
\text { acceptability of } \\
\text { wrist-worn sen- } \\
\text { sors in a Parkin- } \\
\text { sons disease } \\
\text { population fol- } \\
\text { lowing assess- } \\
\text { ment after both } \\
\text { brief and pro- } \\
\text { longed periods } \\
\text { of wearing. }\end{array}$ & $\begin{array}{l}\text { Questionnaire } \\
\text { with Lickert- } \\
\text { style questions } \\
\text { and free-text re- } \\
\text { sponses after } \\
\text { use for } 4 \mathrm{~h} \text { in a } \\
\text { research facility } \\
\text { and after } 1 \text { week } \\
\text { of continuously } \\
\text { use at home. }\end{array}$ \\
\hline
\end{tabular}

\begin{tabular}{|c|c|c|c|}
\hline $\begin{array}{l}\text { Remote monitoring } \\
\text { of symptoms in } \\
\text { Parkinson's disease } \\
\text { PD) (using body-worn } \\
\text { bilateral wrist-worn } \\
\text { sensors. }\end{array}$ & $\begin{array}{l}\text { Both in } \\
\text { a } \\
\text { research } \\
\text { facility } \\
\text { and at } \\
\text { home }\end{array}$ & $\begin{array}{l}\text { A sample of } 34 \\
\text { patients } \\
\text { Age: 50-86 } \\
\text { years (mean } 69 \\
\text { years) } \\
\text { Gender not } \\
\text { reported. } \\
\text { Diagnosis: } \\
\text { Parkinsons } \\
\text { disease. } \\
\text { Average } \\
\text { duration of PD: } \\
10 \text { years (2-26 } \\
\text { years) }\end{array}$ & $\begin{array}{l}94,1 \% \text { were willing } \\
\text { to wear the sensors } \\
\text { at home, and } 85,3 \% \\
\text { to wear it in public. } \\
\text {-The sensors looks } \\
\text { like it is well made } \\
\text {-The sensor is } \\
\text { comfortable to wear } \\
\text {-The sensor does } \\
\text { not feel heavy on } \\
\text { my arm } \\
\text {-The sensor is easy } \\
\text { to take on and off } \\
\text { Appearance: Physical } \\
\text { properties could be } \\
\text { improved. Wearing } \\
\text { in public varied from } \\
\text { not covering it up, } \\
\text { to not like it to be } \\
\text { questioned. } \\
\text { Usability and } \\
\text { Comfort were both } \\
\text { positive and } \\
\text { negative. }\end{array}$ \\
\hline
\end{tabular}

$\begin{array}{lll}\text { Georgsson, } & \text { Patients' } & \text { To understand } \\ \text { Staggers 2017 } & \text { perceptions and } & \text { patients' } \\ \text { Sweden (Swe) } & \text { experiences of a } & \text { perceptions of } \\ \text { [44] } & \text { mHealth diabetes } & \text { (1) longer-term } \\ & \text { self-management } & \text { use of a specific } \\ & \text { system } & \text { mHealth system } \\ & \text { called Care4Life, } \\ & \text { (2) specific im- } \\ & \text { provements } \\ & \text { needed for Car- } \\ & \text { e4Life, and (3) } \\ & \text { their needs for } \\ & \text { future diabetes } \\ & \text { self-management }\end{array}$

\section{Questionnaire} and

semistructured interviews after exit from a 6month randomized controlled trial
Care4Life, an interactive short messaging service (SMS) diabetes selfmanagement system for patients. Patients send in blood glucose, blood pressure, weight, exercises and medication adherence values, and receive reminders and advice about various aspects of their disease.

Patients saw clear sample of 10 benefits in using the patients technology, and had participating in favorable behavioral a larger RCT. disease outcomes Age: $50 \%$ were after using Care4Life. 60-69 years Attitudes: Gender: 5 Positive overall women and 5 system perception men and general

Diagnosis: Type perception. 2 Diabetes Behavioral outcomes: Positive reminder, control and independence. Suggested improvements for behavioral support (highly individual): Information and disease related, and food and lifestyle related support.

To explore the beliefs and perceptions of patients with chronic obstructive pulmonary disease (COPD) currently using home telehealth and who are not enrolled in a trial.
Semistructured interviews with patients who had been using telehealth from 6 months up to 3 years, with a mean of 17 months use.
Small-sized telehealth equipment allowing the patient to attach peripheral devices to take readings of their vital signs, with the individual readings displayed on the equipment. Larger sized telehealth equipment additionally allowed patients to view their data in graphs and charts.
At home A sample of 8 Four superordinate patients as part themes:

of a larger study -perceiving benefits recruiting of "being watched patients with over" as providing COPD and/or peace of mind Chronic heart -learning about the failure.

Age: $58-84$ years (mean 68 years)

Gender: 5 women and 3 men $\begin{array}{ll}\text { men } & \text { provision and better } \\ \text { Diagnosis: } & \text { access to health care }\end{array}$ health condition and the impacts on selfmanagement behaviour -active engagement in health service 
Table 3 Characteristics of articles included in the systematic review of studies exploring patient experiences with technology enabled care $(n=21)$, in alphabetic order (Continued)

\begin{tabular}{|c|c|c|c|c|c|c|c|}
\hline $\begin{array}{l}\text { Authors/ } \\
\text { Country }\end{array}$ & Title & Aim & Design & Technology explored & Setting & $\begin{array}{l}\text { Sample, } \\
\text { including } \\
\text { participants' } \\
\text { characteristics }\end{array}$ & $\begin{array}{l}\text { Summary of relevant } \\
\text { findings }\end{array}$ \\
\hline & & & & & & $\begin{array}{l}\text { COPD } \\
\text { Average } \\
\text { duration of } \\
\text { COPD: } 9 \text { years } \\
\text { (4-18 years) }\end{array}$ & $\begin{array}{l}\text { - valuing the } \\
\text { importance of in- } \\
\text { person care }\end{array}$ \\
\hline $\begin{array}{l}\text { Hanley, Ure, } \\
\text { Pagliari, } \\
\text { Sheikh, } \\
\text { McKinstry } \\
2013 \\
\text { United } \\
\text { Kingdom (UK) } \\
\text { [45] }\end{array}$ & $\begin{array}{l}\text { Experiences of } \\
\text { patients and } \\
\text { professionals } \\
\text { participating in the } \\
\text { HITS home blood } \\
\text { pressure (BP) } \\
\text { telemonitoring } \\
\text { trial: a qualitative } \\
\text { study. }\end{array}$ & $\begin{array}{l}\text { To qualitatively } \\
\text { explore the } \\
\text { experiences of } \\
\text { patients and } \\
\text { professionals } \\
\text { taking part in a } \\
\text { trial of BP } \\
\text { telemonitoring } \\
\text { based in a usual } \\
\text { care setting, to } \\
\text { identify what } \\
\text { contributes to } \\
\text { the effectiveness } \\
\text { of the } \\
\text { intervention, } \\
\text { what limited its } \\
\text { effectiveness and } \\
\text { what may be } \\
\text { required for } \\
\text { success of the } \\
\text { trial to be } \\
\text { translated into } \\
\text { routine care. }\end{array}$ & $\begin{array}{l}\text { Semistructured } \\
\text { interviews } \\
\text { within a RCT of } \\
\mathrm{BP} \\
\text { telemonitoring } \\
\text { in routine care. }\end{array}$ & $\begin{array}{l}\text { A validated electronic } \\
\text { home blood pressure } \\
\text { (BP) monitor and } \\
\text { mobile phone } \\
\text { technology that } \\
\text { enabled the transfer } \\
\text { of BP readings via } \\
\text { SMS to secure } \\
\text { website which was } \\
\text { accessible to the user } \\
\text { and their doctor and } \\
\text { nurse, and also } \\
\text { provided automated } \\
\text { feedback to the } \\
\text { patient. The BP } \\
\text { monitor linked to a } \\
\text { mobile phone } \\
\text { wirelessly, via } \\
\text { Bluetooth. }\end{array}$ & At home & $\begin{array}{l}\text { A sample of } 25 \\
\text { patients ( } 20 \\
\text { from the } \\
\text { intervention } \\
\text { arm and } 5 \text { from } \\
\text { control arm) } \\
\text { Age: } \\
<50 \text { years: } 5 \\
\text { 50-59 years: } 10 \\
70+\text { years: } 10 \\
\text { Gender: } 10 \\
\text { women and } 15 \\
\text { men } \\
\text { Diagnosis: } \\
\text { Hypertension }\end{array}$ & $\begin{array}{l}\text { Patients became } \\
\text { more engaged in } \\
\text { the clinical } \\
\text { management of } \\
\text { their condition. } \\
\text { The home } \\
\text { monitoring system } \\
\text { provided better } \\
\text { evidence for action, } \\
\text { facilitating rapid } \\
\text { tailoring of } \\
\text { medication. } \\
\text { The role of } \\
\text { telemetry-enabled } \\
\text { home monitoring } \\
\text { was motivating, an } \\
\text { incentive to improve } \\
\text { self-care and evi- } \\
\text { dence which facili- } \\
\text { tated meaningful } \\
\text { conversation and } \\
\text { dialogue with } \\
\text { professionals. }\end{array}$ \\
\hline $\begin{array}{l}\text { Jalil, Myers, } \\
\text { Atkinson, } \\
\text { Soden } \\
2019 \\
\text { Australia (AU) } \\
\text { [46] }\end{array}$ & $\begin{array}{l}\text { Complementing a } \\
\text { clinical trial with } \\
\text { human-computer } \\
\text { interaction: Pa- } \\
\text { tients' user experi- } \\
\text { ences with } \\
\text { telehealth }\end{array}$ & $\begin{array}{l}\text { To investigate } \\
\text { how to discover } \\
\text { patients' user } \\
\text { experiences in } \\
\text { telehealth, } \\
\text { eHealth, and } \\
\text { mHealth in a } \\
\text { clinical trial }\end{array}$ & $\begin{array}{l}\text { Semi structured } \\
\text { interviews and } \\
\text { survey within a } \\
\text { RCT. }\end{array}$ & $\begin{array}{l}\text { A tablet computer, an } \\
\text { automatic } \\
\text { glucometer, and an } \\
\text { automatic } \\
\text { sphygmomanometer }\end{array}$ & At home & $\begin{array}{l}\text { A sample of } 9 \\
\text { patients } \\
\text { Age: } 52-74 \\
\text { years (mean } 62 \\
\text { years) } \\
\text { Gender: } 4 \\
\text { women and } 5 \\
\text { men } \\
\text { Diagnosis: Type } \\
2 \text { diabetes } \\
\text { mellitus for at } \\
\text { least } 12 \text { months. }\end{array}$ & $\begin{array}{l}\text { Two themes were } \\
\text { identified: } \\
\text { (1) the current } \\
\text { design and how } \\
\text { that fits with the } \\
\text { patients' needs } \\
\text {-Lack of wireless } \\
\text { capability } \\
\text {-Undesirable } \\
\text { experience from } \\
\text { sphygmomanometer } \\
\text {-Lack of visual data } \\
\text {-Lack of medication } \\
\text { name } \\
\text { - Mismatch with life } \\
\text { due to immobility } \\
\text { of the device } \\
\text { - Glucometer } \\
\text { discomfort and } \\
\text { pain } \\
\text { (2) the patients } \\
\text { experience of using } \\
\text { the device depicted } \\
\text { through their } \\
\text { feelings and } \\
\text { perceptions } \\
\text {-Motivation } \\
\text {-Build a habit } \\
\text {-Awareness } \\
\text {-Feel safe } \\
\text {-Reduced doctor } \\
\text { visits } \\
\text {-Frustrations } \\
\text {-Difficulty in } \\
\text { measurement of }\end{array}$ \\
\hline
\end{tabular}


Table 3 Characteristics of articles included in the systematic review of studies exploring patient experiences with technology enabled care $(n=21)$, in alphabetic order (Continued)

\begin{tabular}{|c|c|c|c|c|c|c|c|}
\hline $\begin{array}{l}\text { Authors/ } \\
\text { Country }\end{array}$ & Title & Aim & Design & Technology explored & Setting & $\begin{array}{l}\text { Sample, } \\
\text { including } \\
\text { participants' } \\
\text { characteristics }\end{array}$ & $\begin{array}{l}\text { Summary of relevant } \\
\text { findings }\end{array}$ \\
\hline
\end{tabular}

\begin{tabular}{|c|c|c|c|}
\hline $\begin{array}{l}\text { Jamison, Mei, } \\
\text { Ross } 2018 \\
\text { USA } \\
\text { (US) [47] }\end{array}$ & $\begin{array}{l}\text { Longitudinal trial } \\
\text { of a smartphone } \\
\text { pain application for } \\
\text { chronic pain } \\
\text { patients: Predictors } \\
\text { of compliance and } \\
\text { satisfaction }\end{array}$ & $\begin{array}{l}\text { To determine the } \\
\text { long-term effects } \\
\text { of using a smart- } \\
\text { phone pain app } \\
\text { that allows } \\
\text { chronic pain pa- } \\
\text { tients to assess, } \\
\text { monitor, and } \\
\text { communicate } \\
\text { their condition to } \\
\text { their physicians } \\
\text { and that offers } \\
\text { pain manage- } \\
\text { ment strategies } \\
\text { for users. }\end{array}$ & $\begin{array}{l}\text { A longitudinal } \\
6 \text {-month trial } \\
\text { using a ques- } \\
\text { tionnaire at } \\
\text { three and six } \\
\text { months. }\end{array}$ \\
\hline
\end{tabular}

An app to assess, monitor and communicate patients' status to their providers. Included an activity monitor and a Fitbit to track daily activity.

$\begin{array}{lll}\text { Kardas, } & \text { Type 2 diabetes } & \text { To assess } \\ \text { Lewandowski, } & \text { patients benefit } & \text { patients' } \\ \text { Bromuri 2016 } & \text { from the } & \text { assessment of } \\ \text { Poland (PL) } & \text { COMODITY12 } & \text { their experience } \\ \text { [38] } & \begin{array}{l}\text { mHealth system: } \\ \text { Results of a } \\ \text { randomised trial. }\end{array} & \text { COMMODITY12 } \\ & & \text { system use } \\ & \text { within 6 weeks' } \\ & \text { long clinical trial } \\ & \text { in DM2 patients- } \\ & \text { the } \\ & \text { "COMMODITY12" } \\ & \text { trial. }\end{array}$

Knudsen,

Laustsen,

Petersen,

Hjortdal,

Angel 2019

Denmark (DK)

[48]
Experience of cardiac telerehabilitation: analysis of patient narratives
To explore patients' experiences of tele-rehabilitation and the pertaking part in the

A 6 weeks RCT
using a
questionnaire at
endpoint

\section{COMMODITY12} system, composed of smart phone, and wireless connected sensors:

-A Bluetooth-enabled glucometer, blood pressure reader and scale

-A Bluetooth-enabled sensor of ECG, heart rhythm, and respiratory movements -A triaxial accelerometer already built in the SmartHub (mobile phone)

-MEMS ${ }^{\mathrm{TM}}$ - a patient adherence monitor, which has been used to assess patient adherence with oral antidiabetic agents they were using ceived gains of program
Interviews after Monitoring a 12-week equipment with a hospital-based heart rate monitor rehabilitation in with a sensor device, an outpatient blood pressure setting (phase II) monitor, weight scale, smartphone with built-in alarm and website. Information
At home A sample of 90 The app was easy to patients with use chronic pain Those who used the Age: 18-79 app more often years (mean 47 were more satisfied years) Satisfaction rating women and 32 diminished over men

Diagnosis: Cancer and noncancerrelated chronic pain for longer than six months time. Greater use of the app and frequent daily assessment entries were found to be related to an overall improvement in mood, but did not have a positive effect on pain or activity. Those who were more satisfied with the app reported more painrelated disability and were less active.

At home A sample of 60 All telehealth system patients (30 dimensions reached from the active mean values of arm and 30 above four in a fivefrom the point scale, with control arm) maximum values for Age: Mean 59 clearness of instrucyears

Gender: 24 women and 36 men Diagnosis: Diabetes type 2 ity of results and for at least six time spent on sysmonths prior to tem use daily. Sysstudy tems users asked for its strengths said system being fast, enabled them systematic selfmonitoring and was easy to use. Weaknesses were frequent need to recharge and problems with glucometer strips.

At home A sample of 7 Patients valued the patients. Age: $46-70$ years (mean 58 years) cardiac telerehabilitation beGender: 7 men hospital setting. Diagnosis: $\quad$ Flexibility was asIschemic heart sumed as an advandisease or tage. If activities undergone were part of their 
Table 3 Characteristics of articles included in the systematic review of studies exploring patient experiences with technology enabled care $(n=21)$, in alphabetic order (Continued)

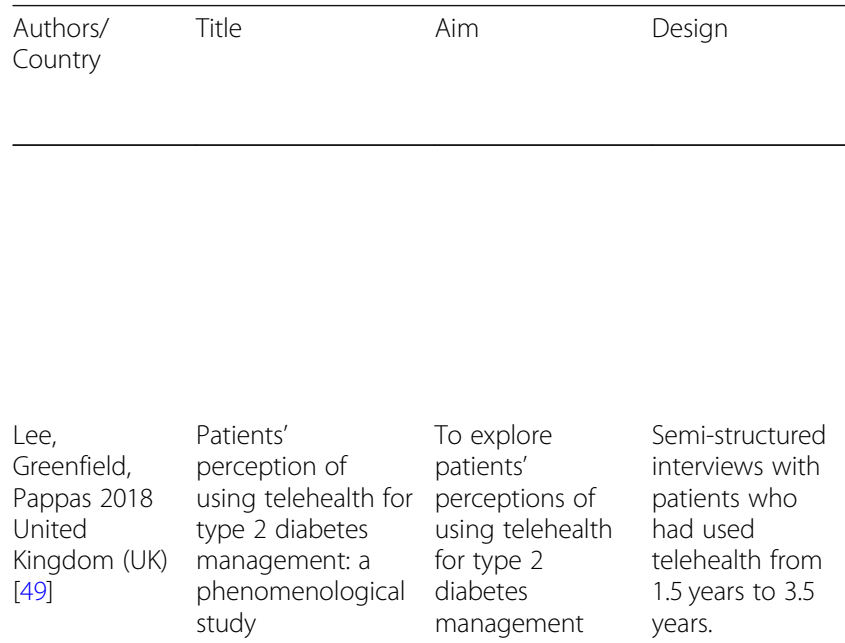

\begin{tabular}{|c|c|c|c|c|}
\hline $\begin{array}{l}\text { Maglalang, } \\
\text { Yoo, Ursua, } \\
\text { Villanueva, } \\
\text { Chesla, } \\
\text { Bender } 2017 \\
\text { USA } \\
\text { (US) [50] }\end{array}$ & $\begin{array}{l}\text { "I don't have to } \\
\text { explain, people } \\
\text { understand": } \\
\text { acceptability and } \\
\text { cultural relevance } \\
\text { of a mobile health } \\
\text { lifestyle } \\
\text { intervention for } \\
\text { Filipinos with Type } \\
2 \text { Diabetes }\end{array}$ & $\begin{array}{l}\text { To access the } \\
\text { acceptability and } \\
\text { cultural relevance } \\
\text { of the PilAm } \\
\text { Go4Health } \\
\text { program }\end{array}$ & $\begin{array}{l}\text { A pilot } \\
\text { randomized } \\
\text { control trial } \\
\text { using semi- } \\
\text { structured post- } \\
\text { program indi- } \\
\text { vidual interviews } \\
\text { after 3-months } \\
\text { intervention and } \\
\text { 3-months } \\
\text { maintenance. }\end{array}$ & $\begin{array}{l}\text { PilAm Go4Health } \\
\text { program. A culturally } \\
\text { adapted mobile } \\
\text { weigth-loss lifestyle } \\
\text { intervention including } \\
\text { virtual social network- } \\
\text { ing. Included using a } \\
\text { Fitbit accelerometer, } \\
\text { self-reporting of food/ } \\
\text { calorie intake and } \\
\text { weight using the Fit- } \\
\text { bit diary app, and par- } \\
\text { ticipate in a private } \\
\text { Facebook group. }\end{array}$ \\
\hline
\end{tabular}

Maguire,

Ream,

Richardson, Connaghan, Johnston, Kotronoulas, Pedersen,

Development of a To (a) explore novel remote the feasibility

A repeated-

The Advanced patient monitoring and acceptability system: the of the Advanced advanced Symptom symptom Management measures, Symptom single-arm, Management Systemmixed-methods $R$ (ASyMS-R) enables study design in- real-time collection of volving post- PROM data as a mostudy semi- bile phone-based

Technology explored
transferred from
smartphone to a
website. The patients
and healthcare
professionals had
access to shared data
on website.

Telehealth to monitor blood glucose, blood pressure and weight.

A sample of 10 patients.

Age: 49-77 years (mean 63 years) Gender: 8 women and 2 men

Diagnosis: Type 2 diabetes for 4 to 33 years, mean time of 15.4 years. daily lives, it lead to greater acknowledgement and commitment to the program. If not, the program was experienced as an extra challenge.

Three themes for facilitating positive patient experience or acceptance of telehealth: Technology consideration -Initial perception of using technology for self-management -Telehealth usability concerns Service perceptions -Sense of security and comfort

-Easy and convenience access to healthcare services -Privacy concerns -Continuity of care Empowerment -Patient education -Supporting self-care with telehealth system's health trend analysis

At home A sample of 45 Four major themes patients (22 were identified: from -Culturally tailored intervention support enhanced group and 23 engagement from an active -Mobile technology wait-list control promoted personal group). agency

Age: Mean 58 -Progression from

years

efficacy

women and 17 -Further cultural men

Diagnosis: Noninsulin dependent tailoring addressing support mechanisms and improved site accessibility were Type 2 Diabetes suggested to improve intervention acceptability.
At home A sample of 16 patients.

Age: 42-85 years (mean 64 years) Gender: 11 women and 5
Only rarely did patients report problems in using the handset. They felt that the system covered all relevant symptoms, helped 
Table 3 Characteristics of articles included in the systematic review of studies exploring patient experiences with technology enabled care $(n=21)$, in alphabetic order (Continued)

\begin{tabular}{|c|c|c|c|c|c|c|c|}
\hline $\begin{array}{l}\text { Authors/ } \\
\text { Country }\end{array}$ & Title & Aim & Design & Technology explored & Setting & $\begin{array}{l}\text { Sample, } \\
\text { including } \\
\text { participants' } \\
\text { characteristics }\end{array}$ & $\begin{array}{l}\text { Summary of relevant } \\
\text { findings }\end{array}$ \\
\hline $\begin{array}{l}\text { McPhelim, } \\
\text { Pattison, } \\
\text { Smith, } \\
\text { Webster, } \\
\text { Taylor, } \\
\text { Kearney } 2015 \\
\text { United } \\
\text { Kingdom (UK) } \\
\text { [15] }\end{array}$ & $\begin{array}{l}\text { system for } \\
\text { radiotherapy to } \\
\text { improve the } \\
\text { symptom } \\
\text { experience of } \\
\text { patients with lung } \\
\text { cancer receiving } \\
\text { radiotherapy. }\end{array}$ & $\begin{array}{l}\text { patients with } \\
\text { lung cancer } \\
\text { receiving } \\
\text { radiotherapy and } \\
\text { clinicians } \\
\text { involved in their } \\
\text { care and (b) } \\
\text { assess changes in } \\
\text { patient } \\
\text { outcomes during } \\
\text { implementation } \\
\text { of the Advanced } \\
\text { Symptom } \\
\text { Management } \\
\text { System with } \\
\text { patients with } \\
\text { lung cancer } \\
\text { receiving } \\
\text { radiotherapy in } \\
\text { clinical practice }\end{array}$ & $\begin{array}{l}\text { structured inter- } \\
\text { views and } \\
\text { semis-structured } \\
\text { questionnaires } \\
\text { at baseline and } \\
\text { end of } \\
\text { treatment. }\end{array}$ & $\begin{array}{l}\text { symptom monitoring } \\
\text { system. Patients re- } \\
\text { ceived self-care ad- } \\
\text { vice on their mobile } \\
\text { phone or alerts were } \\
\text { generated to a pager } \\
\text { held by a health pro- } \\
\text { fessional at the clin- } \\
\text { ical site when } \\
\text { symptoms were of } \\
\text { clinical concern. }\end{array}$ & & $\begin{array}{l}\text { men } \\
\text { Diagnosis: Lung } \\
\text { cancer receiving } \\
\text { radiotherapy }\end{array}$ & $\begin{array}{l}\text { them manage the } \\
\text { symptoms and } \\
\text { effectively } \\
\text { communicate with } \\
\text { clinicians. }\end{array}$ \\
\hline $\begin{array}{l}\text { Minatodani, } \\
\text { Chao, Berman } \\
2013 \\
\text { USA (US) [51] }\end{array}$ & $\begin{array}{l}\text { Home telehealth: } \\
\text { facilitators, barriers, } \\
\text { and impact of } \\
\text { nurse support } \\
\text { among high-risk } \\
\text { dialysis patients. }\end{array}$ & $\begin{array}{l}\text { To evaluate } \\
\text { patients' } \\
\text { perceived } \\
\text { effectiveness of } \\
\text { and satisfaction } \\
\text { with home } \\
\text { telehealth self- } \\
\text { monitoring and } \\
\text { remote care } \\
\text { nurse (RCN) sup- } \\
\text { port and to iden- } \\
\text { tify perceived } \\
\text { facilitators and } \\
\text { barriers encoun- } \\
\text { tered with RT } \\
\text { use. }\end{array}$ & $\begin{array}{l}\text { Mixed methods } \\
\text { approach using } \\
\text { semistructured } \\
\text { interviews as } \\
\text { part of a RCT }\end{array}$ & $\begin{array}{l}\text { Remote technology } \\
\text { to self-monitor the } \\
\text { health (physiological } \\
\text { measurements and } \\
\text { answering } 10 \text { subject- } \\
\text { ive health questions } \\
\text { specific to end-stage } \\
\text { renal disease and dia- } \\
\text { lysis treatment) at } \\
\text { home. }\end{array}$ & At home & $\begin{array}{l}\text { A sample of } 33 \\
\text { patients } \\
\text { Age: } 37-87 \\
\text { years (mean } 60 \\
\text { years) } \\
\text { Gender: } 13 \\
\text { women and } 20 \\
\text { men } \\
\text { Diagnosis: End } \\
\text { stage renal } \\
\text { disease and } \\
\text { dialysis } \\
\text { treatment }\end{array}$ & $\begin{array}{l}\text { Receiving efficient } \\
\text { feedback from RCT. } \\
\text { Were better able to } \\
\text { identify changes in } \\
\text { their health status. } \\
\text { Experienced } \\
\text { enhanced } \\
\text { accountability, self- } \\
\text { efficacy and motiv- } \\
\text { ation to make health } \\
\text { behaviour changes. } \\
\text { The most frequently } \\
\text { cited barriers related } \\
\text { to malfunctioning } \\
\text { equipment or } \\
\text { trouble with Internet } \\
\text { connections, } \\
\text { forgetfulness, and } \\
\text { felling poorly. }\end{array}$ \\
\hline $\begin{array}{l}\text { Nordin, } \\
\text { Michaelson, } \\
\text { Eriksson, Gard } \\
2017 \\
\text { Sweden (Swe) } \\
\text { [52] }\end{array}$ & $\begin{array}{l}\text { It's about me: } \\
\text { patients' } \\
\text { experiences of } \\
\text { patient } \\
\text { participation in the } \\
\text { web behavior } \\
\text { change program } \\
\text { for activity in } \\
\text { combination with } \\
\text { multimodal pain } \\
\text { rehabilitation }\end{array}$ & $\begin{array}{l}\text { To explore } \\
\text { patients' } \\
\text { experiences of } \\
\text { patient } \\
\text { participation in a } \\
\text { Web Behavior } \\
\text { Change Program } \\
\text { for Activity (Web- } \\
\text { BCPA) in } \\
\text { combination } \\
\text { with multimodal } \\
\text { rehabilitation } \\
\text { (MMR) in primary } \\
\text { health care }\end{array}$ & $\begin{array}{l}\text { Semistructured } \\
\text { interviews with } \\
\text { open-ended } \\
\text { questions as } \\
\text { part of a RCT. }\end{array}$ & $\begin{array}{l}\text { Behavior Change } \\
\text { Program for Activity } \\
\text { in combination with } \\
\text { multimodal } \\
\text { rehabilitation (Web- } \\
\text { BCPA). An eHealth } \\
\text { solution for a } \\
\text { biopsychosocial } \\
\text { treatment of } \\
\text { persistent } \\
\text { musculoskeletal pain. } \\
\text { The modules } \\
\text { contained } \\
\text { information, } \\
\text { assignments, } \\
\text { exercises, educational } \\
\text { texts, videos and } \\
\text { writing tasks. }\end{array}$ & At home & $\begin{array}{l}\text { A consecutively } \\
\text { sample of } 19 \\
\text { patients at their } \\
\text { 4-month follow- } \\
\text { up of the RCT. } \\
\text { Age: } 27-60 \\
\text { years (Mean } 45 \\
\text { years) } \\
\text { Gender: } 15 \\
\text { women and } 4 \\
\text { men } \\
\text { Diagnosis: } \\
\text { Persistent } \\
\text { musculoskeletal } \\
\text { pain with a } \\
\text { duration of at } \\
\text { least three } \\
\text { months in the } \\
\text { back, neck, } \\
\text { shoulder and/or } \\
\text { generalized } \\
\text { pain. }\end{array}$ & $\begin{array}{l}\text { One theme: It's } \\
\text { about me with } 4 \\
\text { categories: } \\
\text {-take part in a } \\
\text { flexible framework } \\
\text { of own priority } \\
\text {-acquire knowledge } \\
\text { and insights } \\
\text { - ways towards } \\
\text { change } \\
\text { - personal and } \\
\text { environmental } \\
\text { conditions } \\
\text { influencing } \\
\text { participation }\end{array}$ \\
\hline Reeder, & Older adults' & To examine the & A survey after 9 & The MD.2 medication & At home & A sample of 96 & Nearly all patients \\
\hline
\end{tabular}


Table 3 Characteristics of articles included in the systematic review of studies exploring patient experiences with technology enabled care $(n=21)$, in alphabetic order (Continued)

\begin{tabular}{|c|c|c|c|c|c|c|c|}
\hline $\begin{array}{l}\text { Authors/ } \\
\text { Country }\end{array}$ & Title & Aim & Design & Technology explored & Setting & $\begin{array}{l}\text { Sample, } \\
\text { including } \\
\text { participants' } \\
\text { characteristics }\end{array}$ & $\begin{array}{l}\text { Summary of relevant } \\
\text { findings }\end{array}$ \\
\hline $\begin{array}{l}\text { Demiris, } \\
\text { Marek } 2013 \\
\text { USA (US) [53] }\end{array}$ & $\begin{array}{l}\text { satisfaction with a } \\
\text { medication } \\
\text { dispensing device } \\
\text { in home care. }\end{array}$ & $\begin{array}{l}\text { level of frail older } \\
\text { adults' } \\
\text { satisfaction with } \\
\text { medication } \\
\text { dispensing } \\
\text { device and } \\
\text { assess perceived } \\
\text { usefulness of the } \\
\text { device by older } \\
\text { adult home care } \\
\text { patients. }\end{array}$ & $\begin{array}{l}\text { months as part } \\
\text { of a prospective, } \\
\text { longitudinal, } \\
\text { three-arm RCT } \\
\text { conducted over } \\
\text { a one-year } \\
\text { period }\end{array}$ & $\begin{array}{l}\text { dispensing machine } \\
\text { automatically } \\
\text { dispenses pre-loaded } \\
\text { medication and gives } \\
\text { alerts to individuals } \\
\text { about medication } \\
\text { times. }\end{array}$ & & $\begin{array}{l}\text { patients } \\
\text { Age: mean } 80 \\
\text { years } \\
\text { Gender: } 63 \\
\text { women and } 33 \\
\text { men } \\
\text { Diagnoses: } \\
\text { Chronic } \\
\text { conditions } \\
\text { present } \\
\text { including } \\
\text { diabetes, } \\
\text { depression, } \\
\text { COPD, } \\
\text { dementia and } \\
\text { heart disease. }\end{array}$ & $\begin{array}{l}\text { perceived the } \\
\text { medication } \\
\text { dispensing device as } \\
\text { very easy to use, } \\
\text { very reliable, helpful } \\
\text { in the management } \\
\text { of their medications, } \\
\text { gave them peace of } \\
\text { mind, and they } \\
\text { would like to use } \\
\text { the machine in the } \\
\text { future. }\end{array}$ \\
\hline $\begin{array}{l}\text { Vatnøy, } \\
\text { Thygesen, } \\
\text { Dale } 2017 \\
\text { Norway (NO) } \\
\text { [54] }\end{array}$ & $\begin{array}{l}\text { Telemedicine to } \\
\text { support coping } \\
\text { resources in home- } \\
\text { living patients di- } \\
\text { agnosed with } \\
\text { chronic obstructive } \\
\text { pulmonary disease: } \\
\text { patients' } \\
\text { experiences }\end{array}$ & $\begin{array}{l}\text { To investigate } \\
\text { how the patients } \\
\text { experienced } \\
\text { follow-up using a } \\
\text { TM intervention, } \\
\text { and the extent to } \\
\text { which it sup- } \\
\text { ported and im- } \\
\text { proved coping } \\
\text { resources and } \\
\text { independence. }\end{array}$ & $\begin{array}{l}\text { Individual semi- } \\
\text { structured inter- } \\
\text { views after a } \\
\text { duration of } 10 \\
\text { to } 21 \text { days of } \\
\text { use. }\end{array}$ & $\begin{array}{l}\text { The technological } \\
\text { solution consisted of } \\
\text { 1)a tablet with a } \\
\text { video camera and } \\
\text { pulse oximetry device } \\
\text { for daily monitoring } \\
\text { of pulse and oxygen } \\
\text { saturation transmitted } \\
\text { wirelessly to the } \\
\text { tablet application, 2) } \\
\text { software consisting of } \\
\text { a questionnaire to } \\
\text { measure subjective } \\
\text { symptoms, 3) a } \\
\text { questionnaire for } \\
\text { symptom self- } \\
\text { evaluation The follow- } \\
\text { up included nurse } \\
\text { with real-time follow- } \\
\text { up video } \\
\text { communication }\end{array}$ & At home & $\begin{array}{l}\text { A convenient } \\
\text { sample of } 10 \\
\text { patients } \\
\text { discharged to } \\
\text { their homes } \\
\text { after } \\
\text { hospitalization. } \\
\text { Age: } 55-83 \\
\text { years (mean } 65 \\
\text { years) } \\
\text { Gender: } 3 \\
\text { women and } 7 \\
\text { men } \\
\text { Diagnosis: } \\
\text { COPD } \\
\text { exacerbation }\end{array}$ & $\begin{array}{l}\text { Two themes and } 5 \\
\text { categories: } \\
\text { The TM solution was } \\
\text { experienced as } \\
\text { comprehensible and } \\
\text { manageable and } \\
\text { provided meaning } \\
\text { in daily life. } \\
\text {-Handling and } \\
\text { understanding the } \\
\text { technology } \\
\text {-Feelings related to } \\
\text { technology use } \\
\text { The TM solution } \\
\text { intervention } \\
\text { contributes to stress } \\
\text { reduction caused by } \\
\text { illness burden and } \\
\text { facilitates living as } \\
\text { normally as possible } \\
\text {-Confidence and } \\
\text { trust in the health } \\
\text { service } \\
\text {-Impact on } \\
\text { independence and } \\
\text { self-management } \\
\text {-Integrity and } \\
\text { meaning in life }\end{array}$ \\
\hline $\begin{array}{l}\text { Wall, Ward, } \\
\text { Cartmill, Hill, } \\
\text { Porceddu } \\
2017 \\
\text { Australia (AU) } \\
\text { [55] }\end{array}$ & $\begin{array}{l}\text { Examining user } \\
\text { perceptions of } \\
\text { SwallowIT: a pilot } \\
\text { study of a new } \\
\text { telepractice } \\
\text { application for } \\
\text { delivering intensive } \\
\text { swallowing therapy } \\
\text { to head and neck } \\
\text { cancer patients }\end{array}$ & $\begin{array}{l}\text { To explore } \\
\text { patients' } \\
\text { perceptions of } \\
\text { SwallowlT and } \\
\text { the delivery of } \\
\text { preventive } \\
\text { swallowing } \\
\text { therapy during } \\
\text { CRT via an } \\
\text { asynchronous } \\
\text { telepractice } \\
\text { model. }\end{array}$ & $\begin{array}{l}\text { A mixed } \\
\text { methods } \\
\text { approach using } \\
\text { structured } \\
\text { questionnaire at } \\
\text { baseline and on } \\
\text { completion of } \\
\text { CRT and semi- } \\
\text { structured } \\
\text { phone -inter- } \\
\text { views at 3-12 } \\
\text { months post- } \\
\text { CRT. }\end{array}$ & $\begin{array}{l}\text { An electronic app } \\
\text { hosted on a secure } \\
\text { external server and } \\
\text { provided on a tablet. } \\
\text { The system was } \\
\text { designed to assist } \\
\text { patients to complete } \\
\text { independent home- } \\
\text { practice of preventa- } \\
\text { tive swallowing exer- } \\
\text { cises during CRT, and } \\
\text { included instructional } \\
\text { videos, images and } \\
\text { text. Free text for } \\
\text { communication be- } \\
\text { tween patient and } \\
\text { speech pathologist. }\end{array}$ & & $\begin{array}{l}\text { A sample of } 15 \\
\text { patients } \\
\text { Age: } 46-70 \\
\text { years (mean } 59 \\
\text { years) } \\
\text { Gender: } 15 \text { men } \\
\text { Diagnosis: } \\
\text { Oropharyngeal } \\
\text { squamous cell } \\
\text { carcinoma (SCC) } \\
\text { planned for } \\
\text { curative-intent } \\
\text { chemo- } \\
\text { radiotherapy }\end{array}$ & $\begin{array}{l}\text { Patients felt } \\
\text { comfortable, } \\
\text { confident, } \\
\text { motivated, } \\
\text { supported, and that } \\
\text { the method was } \\
\text { effective. } \\
\text { Few technical } \\
\text { difficulties, and } \\
\text { would not prefer } \\
\text { face-to-face consult- } \\
\text { ation in hospital. } \\
\text { Themes identified } \\
\text { were: } \\
\text {-"It was really easy } \\
\text { to use" (design, } \\
\text { system inclusions, } \\
\text { convenience) } \\
\text {-"You're motivated }\end{array}$ \\
\hline
\end{tabular}


Table 3 Characteristics of articles included in the systematic review of studies exploring patient experiences with technology enabled care $(n=21)$, in alphabetic order (Continued)

\begin{tabular}{lllll}
\hline $\begin{array}{l}\text { Authors/ } \\
\text { Country }\end{array}$ & Title Aim & Design & Technology explored Setting $\begin{array}{l}\text { Sample, } \\
\text { including } \\
\text { participants' } \\
\text { characteristics }\end{array}$ & $\begin{array}{l}\text { Summary of relevant } \\
\text { findings }\end{array}$ \\
\hline
\end{tabular}

to do something"

(extrinsic and intrinsic motivators)

-"Difficult

circumstances"

(treatment sideeffects, time constraints) -"You're on the right track, but..." (Service delivery preferences, design preferences).

\begin{tabular}{|c|c|c|}
\hline $\begin{array}{l}\text { Welch, Balder, } \\
\text { Zagarins } 2015 \\
\text { United } \\
\text { Kingdom (UK) } \\
{[56]}\end{array}$ & $\begin{array}{l}\text { Telehealth } \\
\text { program for type } 2 \\
\text { diabetes: usability, } \\
\text { satisfaction, and } \\
\text { clinical usefulness } \\
\text { in an urban } \\
\text { community health } \\
\text { center. }\end{array}$ & $\begin{array}{l}\text { To examine the } \\
\text { usability, } \\
\text { satisfaction, and } \\
\text { clinical impact of } \\
\text { a 3-month dia- } \\
\text { betes telehealth } \\
\text { intervention for } \\
\text { poorly controlled } \\
\text { type } 2 \text { diabetes } \\
\text { (T2D) patients. }\end{array}$ \\
\hline
\end{tabular}

\begin{tabular}{|c|c|c|c|}
\hline $\begin{array}{l}\text { Woodend, } \\
\text { Sherrard, } \\
\text { Fraser, } \\
\text { Stuewe, } \\
\text { Cheung, } \\
\text { Struther } 2008 \\
\text { USA (US) [57] }\end{array}$ & $\begin{array}{l}\text { Telehome } \\
\text { monitoring in } \\
\text { patients with } \\
\text { cardiac disease } \\
\text { who are at high } \\
\text { risk of readmission. }\end{array}$ & $\begin{array}{l}\text { To determine } \\
\text { whether } \\
\text { telehome } \\
\text { monitoring of } \\
\text { patients with } \\
\text { cardiac disease at } \\
\text { high risk of } \\
\text { readmission } \\
\text { would reduce } \\
\text { hospital } \\
\text { readmissions, } \\
\text { improve } \\
\text { functional status, } \\
\text { and improve } \\
\text { quality of life } \\
\text { over usual care. }\end{array}$ & $\begin{array}{l}\text { A randomized } \\
\text { controlled trial } \\
\text { using a } \\
\text { questionnaire at } \\
1 \text { month, } 3 \\
\text { months, and } 1 \\
\text { year } \\
\text { postdischarge } \\
\text { for } \\
\text { datacollection. }\end{array}$ \\
\hline
\end{tabular}

\begin{tabular}{|c|c|c|c|c|}
\hline $\begin{array}{l}\text { A queationnaire } \\
\text { at the 3-month } \\
\text { follow-up }\end{array}$ & $\begin{array}{l}\text { An electronic pillbox } \\
\text { integrated into an } \\
\text { existing diabetes } \\
\text { remote home } \\
\text { monitoring (RHM) } \\
\text { device suite } \\
\text { comprising a } \\
\text { Blutooth -enabled } \\
\text { blood glucose meter } \\
\text { and an automatic } \\
\text { blood pressure } \\
\text { monitor connected to } \\
\text { a cellular hub for data } \\
\text { uploaded to a clinical } \\
\text { application. } \\
\text { Telehealth nurse } \\
\text { received regular RHM } \\
\text { data alerts and called }\end{array}$ & At home & $\begin{array}{l}\text { A sample of } 29 \\
\text { patients } \\
\text { Age: mean } 61 \\
\text { years } \\
\text { Gender: } 17 \\
\text { women and } 12 \\
\text { men } \\
\text { Diagnosis: } \\
\text { Diabetes type 2, } \\
\text { not on multiple } \\
\text { daily insulin } \\
\text { therapy }\end{array}$ & $\begin{array}{l}\text { High ratings of } \\
\text { usability and } \\
\text { program satisfaction } \\
\text { from patients. } \\
\text { Patients reported } \\
\text { the home } \\
\text { monitoring devices } \\
\text { to be easy to use, } \\
\text { easy to fit into daily } \\
\text { routines and set up } \\
\text { in a convenient } \\
\text { place at home. The } \\
\text { pillbox was in } \\
\text { addition helping to } \\
\text { organize } \\
\text { medications, and } \\
\text { easy to understand } \\
\text { how to refill. }\end{array}$ \\
\hline
\end{tabular}
patients by phone at scheduled intervals.

3 months of video conferencing with a nurse, daily transmission of weight and blood pressure, and periodic transmission of 12lead electrocardiogram. Data were transmitted by telephone lines.
At home A sample of 124 Overall, the equipment was easy patients equipment was $\begin{array}{ll}\text { discharged from } & \text { to use. Some } \\ \text { hospital } & \text { difficulties with ECG }\end{array}$ Age: mean 66 and Video- years conferencing. Gender: $75 \% \quad$ Relieved of worries. men Increased Diagnosis: 62 confidence. patients with heart failure and 62 with angina

(1)


take part in a flexible framework of own priority [52]. A study on telemonitoring in motor neuron disease found that patients emphasized the benefits of timely intervention, reducing unnecessary actions and doctors' visits [40].

Several studies emphasized the importance of patient participation, understood as taking part in a structured and flexible concept with opportunities to influence and a variety of treatments to choose according to one's own needs and priorities. A reasoning process between health care professionals, e.g. reading and documenting in the patient records was perceived as patient participation $[39,45,52]$. As an example, cardiac telerehabilitation was valued due to the flexibility, and that healthcare services were not restricted to the hospital setting. When activities were part of the patients' daily lives, it lead to greater acknowledgement and commitment to the program. Otherwise, the program was experienced as an extra challenge [48].

Timely interventions were perceived as a result of regular monitoring of clinical information, contributing to both physical and psychological well-being. Participants appreciated their data being monitored by professionals who would make timely actions if they saw any irregular signs [40]. Technology enabled care solutions lead to a feeling of security, continuity of care, stress reduction, integrity, meaning and reassurance $[41,45,49$, 54, 57, 61]. For example, COPD patients perceived benefits of "being watched over" as providing peace of mind [39].

\section{Discussion}

In this integrative review, 4098 journal articles were screened, and 21 articles were included which explored patients' experiences with technology enabled care solutions. The integrative analysis showed that patients' experiences were divided into two main aspects; technical features and evolving independence. Technical features was linked to functionality and appearance, while evolving independence was linked to empowerment, autonomy and security. Technology enabled care encompass a variety of instruments and modes of application. The interventions may be provided as an alternative to, in addition to, and/or alongside traditional healthcare services [62]. This integrative review did not limit to year, condition, disease (other than somatic), sociodemographics or study location. Hence, findings here give an insight into patient experiences with technology enabled care varying from telemonitoring to the use of applications, across age, gender, socio-cultural or geographic settings or diseases.

Even though we did not limit the search and inclusion criteria, all studies were conducted in patients receiving technology enabled treatment and/or care in their homes. Many countries struggle to stimulate digitalization and the adoption of digital services to improve health system performance, and to evaluate whether it actually improves health care. It is claimed that the results of digital transformation of health services will depend on the quality of the process, and the involved stakeholders [63].

The European Commision emphasize that further research is needed to evaluate digital health services' potential to strengthen patient empowerment and provision of a basis for shared decision-making. Moreover, the Commision claim that there is insufficient data readily available to systematically assess the value of digital services [63]. This integrative review indicate that patients experience an evolving independence, due to empowerment, autonomy and security from using TEC.

Studies have documented feasibility and high patient adherence and satisfaction, but little evidence have been presented on impact on health outcomes [64, 65]. Findings in this integrative review show that studies focusing on 'satisfaction' most freequently use survey as method. In the studies included, most patients reported to be 'satisfied' with the technology. For example, one study showed that $67 \%$ of the participants $(n=124)$ were very satisfied, and $93 \%$ reported that they were willing to receive home telecare services in the future [57].

This integrative review shows that patient experiences increased empowerment through technology enabled care solutions. There is still no agreement regarding the elements that define patient empowerment. A recent review of the issue found 17 different definitions and described ten possible dimensions in empowerment [66]. Examples were patient participation in clinical decisionmaking, gaining control, motivation and knowledge acquisition [66]. A recent study highlight the perception of direct control on their treatment as the least valued element (2.87, SD 0.566) compared with care quality (3.75, SD 0.649) and relational support in the care context (3.91, SD 0.274) [67]. These dimensions coincide well with what patients experience as benefits of technology enabled care solutions.

In the studies included in this integrative review the mean age was 61.9 years. Moreover, age range was 18 88 . In the US, $86 \%$ of adults aged 65 or older suffer from one or more chronic health conditions [68]. The concept of assisting the older adult through the use of technology so as to access healthcare services has been claimed to have enormous potential [69]. In one study, younger age was associated with greater technology use in health care, as well as capacity to engage in different aspects of health care activities [70]. Hence, high age may have impacted the findings in this study.

The successful implementation of innovative digital technology in healthcare services is a complex and time- 
consuming process. Digital transformation of the healthcare services requires advanced IT competence to be integrated directly into the provision of care and value cocreation with service users; healthcare personnel, patients and their relatives [71]. It has been claimed that eHealth implementation only leads to sustainable adoption when the implementation take into consideration, and aligns the e-Health content, with present contextual structures and the interventions in the implementation process [72]. For example, the study on digital medicine dispensers showed that healthcare professionals' personal justification and rationale for such action is necessary, because their opinions and approval influence whether patients welcome this initiative or not [73].

Earlier studies focus on specific conditions, TECs, or healthcare levels. Findings in this study adds knowledge about patients' experiences with a variety of TECs, across healthcare service levels and irrespective of patients' condition. Since patient experiences' provide more tangible information on how a service can be improved, and is less to prone to the influence of patient expectation [26-29], this information is important to include when developing and implementing TECs in the future.

\section{Strengths and limitations}

The strength of this integrative review is that it is based on close collaboration with a specialized librarian who assisted in setting up search strategies, combinations and boolean operators. Moreover, screening of titles, abstracts and full-text of the records, quality appraisals, as well as the analysis, were conducted in close collaboration between the four authors. Any disagreements were discussed until consensus was reached. This process increases the validity and reliability of this systematic review.

The integrative review has several possible limitations. Firstly, we could have found more studies if we had searched in more databases. Nevertheless, the selected databases are the largest and most relevant for this specific research field and aim. Secondly, we limited our inclusion of articles to those of 'high quality', which may have excluded articles that could have added interesting information about patient experiences.

In addition, we could have included qualitative articles only, since qualitative approaches are more sufficient when aiming to explore experiences and perspectives [74]. Nevertheless, the quantitative studies mainly added information about positive and/or negative experiences, while the qualitative studies added in-depth information about challenges. Several of the studies used mixedmethods approaches, arguing the same. An integrative review method allows for a more comprehensive understanding of patient experiences with digital health solutions in a wide, somatic, healthcare approach [75].

One inclusion criteria was Scandinavian or English language. This may have excluded potentially useful studies, yet there is evidence that limiting studies in this way does not introduce significant bias [76]. We did not limit studies by year. This research area is evolving, and the number of publications has increased rapidly the last ten years. The first study in the literature search was from 1975, while the first included study undertaken quality appraisal and included was from 2008. The earliest studies focused on telehealth initiatives. By not limiting to year, we were able to explore studies in a wide, retrospective perspective, ensuring that we did not oversee any publications of interest.

In this integrative review we assess patients' experiences. Of course, relatives' and healthcare personnel's experiences would have given more in-depth knowledge on different stakeholders' experiences with specific technology or digital solutions, which also may impact patients' experiences in total.

Scholars have debated whether research synthesis differences characterizing efforts to integrate qualitative research findings with the differences characterizing efforts to integrate quantitative research findings preclude mixed research synthesis [31]. Sandelowski et al. [31] claim that both qualitative and quantitative studies can be viewed as producing findings that can readily be transformed into each other. Aiming to explore patients' experiences, we think that quantitative data as much as qualitative data adds to this knowledge.

\section{Conclusion}

This integrative review deepens the understanding of patients' experiences with technology enabled care solutions. Findings indicate that patients' experiences not only relate to the practical or technical element of the device or solution, but to how this impact on their everyday life. Technology enabled care will probably be an imperative part of a comprehensive patient pathway in future healthcare services. Patient participation in development, implementation and utilization of such solutions should be considered an integral part in healthcare quality initiatives.

\section{Supplementary information}

Supplementary information accompanies this paper at https://doi.org/10. 1186/s12913-020-05633-4.

\section{Additional file 1.}

\section{Abbreviations}

CASP: The Critical Appraisal Skills Program (CASP); PRISMA: Preferred Reporting Items for Systematic Reviews and Meta-Analyses guidelines; TEC: Technology enabled care 


\section{Acknowledgements}

Librarians Anne Katrine Gullvåg and Svanbjörg Asudottir isare acknowledged for contributing in setting up search strategies, combinations and boolian operators.

\section{Authors' contributions}

$A C L$ participated in planning the study, the literature search, screening of title/abstracts and full-text records, quality assessment of the full-text records, analysis of data, and writing of the whole draft of the manuscript. CH participated in planning the study, the literature search, screening of title/abstracts and full-text records, quality assessment of the full-text records, and analysis of data, as well as input to drafting, and final approval of the manuscript. AKH participated in planning the study, screening of title/abstracts and fulltext records, quality assessment of the full-text records, and analysis of data as well as input to drafting, and final approval of the manuscript. VAG participated in planning the study, screening of title/abstracts and full-text records, quality assessment of the full-text records, analysis of data, and writing the draft of the methods section, inputs and final approval to the manuscript. All authors read and approved the final manuscript.

\section{Funding}

The study was funded by Ostfold University College. The funding body had no impact on the design of the study, data collection, analysis, interpretation of data, and did not take part in writing the manuscript.

\section{Availability of data and materials}

Overview of excluded records, search strings and other background material of the current study are available from the corresponding author on reasonable request.

\section{Ethics approval and consent to participate}

Not applicable.

\section{Consent for publication}

Not applicable.

\section{Competing interests}

The authors declare to have no competing interests to report.

Received: 4 May 2020 Accepted: 6 August 2020

Published online: 24 August 2020

\section{References}

1. St Sauer J, Boyd C, Grossardt B, Bobo W, Finney R, Roger V, et al. Risk of developing multimorbidity across all ages in an historical cohort study: differences by sex and ethnicity. BMJ Open. 2015;5(2).

2. Uijen A, van de Lisdonk E. Multimorbidity in primary care: prevalence and trend over the last 20 years. Eur J General Pract. 2008;14(1):28-32.

3. Van Bokkelen G, Morsy M, Kobayashi T. Demographic transition, health care challenges, and the impact of emerging international regulatory trends with relevance to regenerative medicine. Curr Stem Cell Rep. 2015;1:102-9.

4. OECD. Health at a Glance 2019. OECD Indicators 2019. http://www.oecd. org/health/health-systems/health-at-a-glance-19991312.htm.

5. Bureau of Labor Statistics. Employment projection. 2017. https://data.bls. goc/projections/occupationProj. Accessed 20 March 2020.

6. Taylor K. Connected health. How digital technology is transforming health and social care. Deloitte: London, UK; 2015.

7. Drumm J, White N, Swiegers M. Mobile consumer survey 2016- the Australian cut. Deloitte: Sydney; 2016.

8. Lyons A. Applications for health. Good Practice. 2017;7:10-3.

9. Pew Research Center. The future of apps and web. 2012. https://www. pewresearch.org/internet/2012/03/23/the-future-of-apps-and-web/. Accessed 3 April 2020.

10. World Health Organization. mHealth: New horizons for health through mobile technologies. 2015. https://www.who.int/goe/publications/goe_ mhealth_web.pdf. Accessed 15 March 2020.

11. Nordheim L, Haavind M, Iversen M. Effect of telemedicine follow-up care of leg and foot ulcers: a systematic review. BMC Health Serv Res. 2014;14:565.

12. Peterson A. Improving type 1 diabetes management with mobile tools: a systematic review. J Diabetes Sci Technol. 2014;8(4):859-64.
13. Gorst S, Armitage C, Brownsell S, Hawley M. Home telehealth uptake and continued use among heart failure and chronic obstructive pulmonary disease patients: a systematic review. Ann Behav Med. 2014; 48(3):323-36

14. Grustam A, Severebs J, van Nijnatten J, Koymans R, Vrijhoef H. Costeffectiveness of telehealth interventions for chronic heart failure patients: a literature review. Int J Technol Assess Health Care. 2014;30(1):59-68.

15. Maguire R. eHealth and remote patient monitoring and supportive care in thoracic oncology. J Thoracic Surg. 2017;12(1):202-3.

16. Mooney KH, Beck SL, Wong B, Dunson W, Wujcik D, Whisenant M, et al. Automated home monitoring and management of patient-reported symptoms during chemotherapy: results of the symptom care at home RCT. Cancer Medicine. 2017:6(3):537-46.

17. Guanais F. Patient empowerment can lead to improvements in health-care quality. Bull World Health Org. 2017;95:489-90.

18. McCance T, McCormack B, Dewing J. An exploration of person-centredness in practice. Online J Iss Nurs. 2011;16(2):1.

19. Miles A, Asbridge J. Clarifying the concepts, epistemology and lixicon of person-centredness: an essential pre-requisite for the effecitve operationalization of PCH within modern healthcare systems. Eur J Person Centered Healthcare. 2014;2(1):1-15.

20. Miles A, Asbridge J. The chronic illness problem. The person-centered solution. Eur J Person Centered Healthcare. 2016;4(1):1-5.

21. Doyle C, Lennox L, Bell D. A systematic review of evidence on the links between patient experience and clinical safety and effectiveness. BMJ Open. 2013;3(1):e001570

22. Garratt A, Sullivan M, Danielsen K. National and cross-national surveys of patient experiences: a structured review. Norwegian Knowledge Centre for the health services; 2008.

23. Tomlinson J. Shifting the focus of shared decision making to human relationships. BMJ. 2018;360:53.

24. Kasper J, Lager AR, Rumpsfeld M, Kienlin S, Smestad KH, Bråthen T, et al. Status report from Norway: implementation of patient involvement in Norwegian health care. Zeitschrift für Evidenz, Fortbildung und Qualität im Gesundheitswesen. 2017;123:75-80.

25. Rand L, Dunn M, Slade I, Upadhyaya S, Sheehan M. Understanding and using patient experience as evidence in healthcare priority setting. Cost Eff Resour Alloc. 2019;17(20).

26. Morris B, HJahangir A, Sethi M. Patient satisfaction: an emerging health policy issue. Am Acad Orthop Surg. 2013;9:29.

27. Bleich $\mathrm{S}$. How does satisfaction with the health-care system relate to patient experience? Bull World Health Organ. 2009;87:271-8.

28. Ilioudi S, Lazakidou AASKM, Tsironi M. Importance of patient satisfaction measurement and electronic surveys: methodology and potential benefits. Int J Health Res Innov. 2013;1:67-87.

29. Male L, Noble A, Atkinson J, Marson T. Measuring patient experience: a systematic review to evaluate pshycometric properties of patient reported experience measures (PREMs) for emergency care service provision. Int J Qual Health Care. 2017:29(3):314-26.

30. Malasinghe L, Ramzan N, Dahal K. Remote patient monitoring: a comprehensive study. J Ambient Intell Human Comput. 2017:10:57-76.

31. Sandelowski M, Voils C, Barroso J. Defining an designing mixed research synthesis studies. Res Sch. 2006;13:29-44.

32. Mourad O, Hammady H, Fedorowicz Z, Elmagarmid A. Rayyan- a web and mobile app for systematic reviews. Systematic Reviews. 2016:5:210.

33. Moher D, Liberati A, tetzlaff J, Altman D. Preferred reporing items for systematic reviews and meta-analyses: the PRISMA statement. PLOS Med. 2009;6(7):e0000097.

34. University of Canberra Library. Evidence-based practice in health. The PICO Framework. https://canberra.libguides.com/c.php?g=599346\&p=4149722. Accessed 16 Feb 2020.

35. CASP. CASP Checklists 2019. https://casp-uk.net/casp-tools-checklists/. Accessed 10 Jan 2020

36. Nordström G, Wilde-Larsson B. Assessment tool- quantitative studies. Karlstad, Sweden: Karlstad University; 2006.

37. Higgins J. Thomas S. The Cochrane Collaboration: Cochrane handbook for systematic reviews of interventions; 2019. https://training.cochrane.org/ handbook\#how-to-access.

38. Kardas P, Lewandowski K, Bromuri S. Type 2 Diabetes Patients Benefit from the COMODITY12 mHealth System: Results of a Randomised Trial. J Med Systems. 2016;40 (12) (no pagination)(259). 
39. Gorst S, Coates L, Armitage C. "It's sort of a lifeline": chronic obstructive pulmonary disease patients experiences of home telehealth. Health Psychol. 2016;35.

40. Ando H, Aschcroft-Kelso H, Halhead R, Chakrabarti B, Young C, Cousins R, et al. Experience of telehealth in people with motor neurone disease using noninvasive ventilation. Disabil Rehabil Assist Technol. 2019:12:1-7.

41. Cherry C, Chumbler N, Richards K, Huff A, Wu D, Tilghman L, et al. Expanding stroke telerehabilitation services to rural veterans: a qualitative study on patient experiences using the robotic stroke therapy delivery and monitoring system program. Disabil Rehabil Assist Technol. 2015:12(1):21-7.

42. Fairbrother P, Pinnock H, Hanley J, McCloughan L, Sheikh A, Pagliari C, et al. Exploring telemonitoring and self-management by patients with chronic obstructive pulmonary disease: a qualitative study embedded in a randomized controlled trial. Patient Educ Counsel. 2013;93(3):403-10.

43. Fisher J, Hammerla N, Rochester L, Andras P, Walker R. Body-worn sensors in parkinson's disease: evaluating their acceptability to patients. Telemed J E Health. 2016;22(1):63-9.

44. Georgsson M, Staggers N. Patients' perceptions and experiences of a mHealth diabetes self-management system. CIN. 2017;35(1).

45. Hanley J, Ure J, Pagliari C, Sheikh A, McKinstry B. Experiences of patients and professionals participating in the HITS home blood pressure telemonitoring trial: A qualitative study. BMJ Open. 2013;3 (5) (no pagination)(002671).

46. Jalil S, Myers T, Atkinson I, Soden M. Complementing a clinical trial with human-computer interaction: patients' user experience with telehealth. JMIR Hum Factors. 2019;6(2):9481.

47. Jamison RN, Mei A, Ross EL. Longitudinal trial of a smartphone pain application for chronic pain patients: predictors of compliance and satisfaction. J Telemed Telecare. 2018;24(2):93-100.

48. Knudsen M, Laustsen S. Petersen a, Hjortdal V, angel S. experience of cardiac tele-rehabilitation: anaysis of patient narratives. Disabil Rehabil. 2019: $1-8$.

49. Lee H, Uhm KE, Cheong IY, Yoo JS, Chung SH, Park YH, et al. Patient Satisfaction with Mobile Health (mHealth) Application for Exercise Intervention in Breast Cancer Survivors. J Med Systems. 2018;42 (12) (no pagination)(254)

50. Maglalang D, Yoo G, Ursua R, Villanueva C, Chaesla C, Bender M. "I don't have to explain, people understand": acceptability and cultural relevance of a mobile health lifestyle intervention for Filipinos with type 2 diabetes. Ethn Dis. 2017;27(2):143-54

51. Minatodani D, Chao P, Berman S. Home telehealth: facilitators, barriers, and impact of nurse support among high-risk dialysis patients. Telemed J E Health. 2013;19(8):573-8

52. Nordin C, Michaelson P, Eriksson MK, Gard G. It's about me: patients' experiences of patient participation in the web behavior change program for activity in combination with multimodal pain rehabilitation. J Med Internet Res. 2017;19(1):e22.

53. Reeder B, Demiris G, Marek KD. Older adults' satisfaction with a medication dispensing device in home care. Inform Health Soc Care. 2013;38(3):211-22.

54. Vatnøy T, Thygesen E, Dale B. Telemedicine to support coping resources in home-living patients diagnosed with chronic obstructive pulmonary disease: patients' experiences. J Telemed Telecare. 2017;23(1):126-32.

55. Wall LR, Ward EC, Cartmill B, Hill AJ, Porceddu SV. Examining user perceptions of SwallowIT: a pilot study of a new telepractice application for delivering intensive swallowing therapy to head and neck cancer patients. J Telemed Telecare. 2017:23(1):53-9.

56. Welch G, Balder A, Zagarins S. Telehealth program for type 2 diabetes: usability, satisfaction and clinical usefulness in an urban community health center. Telemed J E Health. 2015;21(5).

57. Woodend AK, Sherrard H, Fraser M, Stuewe L, Cheung T, Struthers C. Telehome monitoring in patients with cardiac disease who are at high risk of readmission. Heart Lung. 2008;37(1):36-45.

58. Magnus M, Sikka N, Cherian T, Lew SQ. Satisfaction and improvements in peritoneal Dialysis outcomes associated with Telehealth. Applied Clin Informatics. 2017:8(1):214-25.

59. Lie S, Karlsen B, Oord E, Graue M, Oftedal B. Dropout from an ehealth intervention for adults with type 2 diabetes: a qualitative study. J Med Internet Res. 2017;19(5):187

60. Bartlett YK, Webb TL, Hawley MS. Using persuasive technology to increase physical activity in people with Chronic Obstructive Pulmonary Disease by encouraging regular walking: A mixed-methods study exploring opinions and preferences. J Med Internet Res. 2017;19(4):1-.
61. Maguire R, Ream E, Richardson A, Connaghan J, Johnston B, Kotronoulas G, et al. Development of a novel remote patient monitoring system: the advanced symptom management system for radiotherapy to improve the symptom experience of patients with lung cancer receiving radiotherapy. Cancer Nurs. 2015;38(2):E37-47.

62. Gregersen T, Green A, Frausing E, Rinbæk T, Brøndum E, Suppli U. Do telemedical interventions improve quality of life in patients with COPD? A systematic review. Int J Chron Obstruct Pulmon Dis. 2016;11(809-22).

63. Comission E. Assessing the impact of difital transformation of health services. Luxembourg: Report of the expert panel on effective ways of investing in health; 2019. https://ec.europa.eu/health/expert panel/sites/ expertpanel/files/docsdir/022_digitaltransformation_en.pdf.

64. Chen AT, Wu S, Tomasino KN, Lattie EG, Mohr DC. A multi-faceted approach to characterizing user behavior and experience in a digital mental health intervention. J Biomed Informatics. 2019:94:103187.

65. Kontronoulas G, Kearney N, Maguire R. What is the value of the routine use of patient-reported outcome measures toward improvement of patient outcomes, processess of care, and health service outcomes in cancer care? A systematic review of controlled trials. J Clin Oncol. 2014;32:1480-501.

66. Cerezo P, Juve-Udina M, Delgado-Hito P. Concepts and measures of patient empowerment: a comprehensive review. J Sch Nurs. 2016;50(4):664-71.

67. Bailo L, Guiddi $P$, Vergani L, Martion G, Pravettoni G. The patient perspective: investigating patient empowerment enablers and barriers within the oncological care process. Ecancer Med Sci. 2019;13:912.

68. Ward BW, Schiller JS, Goodman RA. Multiple chronic conditions among US adults: a 2012 update. 2014 www.cdc.gov/pcd/issues/2014/pdf/13 0389.pdf.

69. van Zaalen Y, McDonnell M, Mikołajczyk B, Buttigieg S. Requena MdC, Holtkamp F. technology implementation in delivery of healthcare to older people: how can the least voiced in society be heard? J Enabl Technol. 2018;12(2):76-90.

70. Sun R, Linden W, Barnett S, Deyo P, Swartwout E. Socio-demographic predictors associated withcapacity to engage in health care. Patient Exper $\mathrm{J}$. 2019;6(2):8.

71. Dugstad J, Eide T, Nilsen E, Eide H. Towards a succesful digital transformation through co-creation: alongitudinal study of a four-year implementation of digital monitoring technology in residental care for persons with dementia. BMC Health Serv Res. 2019;19(366).

72. Hage $E$, Roo J, van Offenbeek M, Boonstra A. Implementation factors and their effect on e-Health service adpotion in rural communities: a systematic literature review. BMC Health Serv Res. 2013;13(19).

73. Nakrem S, Solbjør M, Pettersen I, Kleiven H. Care realtionships at stake? Home healthcare professionals' experiences with digital medicine dispensers- a qualitative study. BMC Health Serv Res. 2018;18(26).

74. Langdridge D. Phenomenological psychology: theory, research and method. Pearson education: Harlow, UK; 2007

75. Whittemore R, Knafl K. The integrative review: updated methodology. J Adv Nurs. 2005;52:546-53.

76. Morrison AP, Polisena J, Husereau D, Moulton K, Clark M, Fiander M, et al. The effect of english-language restriction on systematic review-based metaanalyses: a systematic review of empirical studies. Int J Technol Assess Health Care. 2012:28:138-44.

\section{Publisher's Note}

Springer Nature remains neutral with regard to jurisdictional claims in published maps and institutional affiliations.

Ready to submit your research? Choose BMC and benefit from:

- fast, convenient online submission

- thorough peer review by experienced researchers in your field

- rapid publication on acceptance

- support for research data, including large and complex data types

- gold Open Access which fosters wider collaboration and increased citations

- maximum visibility for your research: over $100 \mathrm{M}$ website views per year

At $\mathrm{BMC}$, research is always in progress.

Learn more biomedcentral.com/submission 